\title{
Editorial: Making the Non-business Case for Development
}

\section{WENDY HARCOURT}

This is the final Development journal issue in Volume 54 on 'Sustainability'. The volume so far has covered global land grabs, the multifaceted challenges to sustainability and sustainable cities. This fourth issue turns to cosmovisions and critical alternatives to western economic development. Any critique of 'mainstream' ideology - be it 'western,'non-western', alternative or otherwise - is politically charged and we need to pay attention to these politics. The debate around sustainability in the earlier issues pivoted around the negative impact of the dominant model of development. In the name of economics, modernity and progress development has ridden rough shod over non-western cultures, exploiting natural resources and local peoples' traditional livelihoods. The articles pointed to the presumptions of overseas development aid and its hopeful claims that development delivered by rich countries to the poor will bring freedom, democracy and well-being to all. The current multiple global crises of climate, finance, food, fuel and care, deepening levels of inequality and continuing war and violence in many areas in the Global South was given as evidence of neo-liberal capitalism failure to deliver. The authors with knowledge and experience from all over the world, depicted how people working in development, with mostly honest good intent, are caught in a dilemma: how to change inequalities, promote well-being, respect for the environment and human rights within a system that is geared mostly to profit, that is benefiting less and less the people it claims to be reaching, and destroying the environments and cultures where they live.

Some have turned to business as the answer. At the SID World Congress held in Washington, DC in July 2011, there were many making the 'business case' for development. This was evident in the sponsorship of the Conference and the bustling stands of companies that thronged the corridors of the Hotel venue. Throughout the sessions the focus was on what had to change in development given that the state-led development could not deliver. Attention to gender was loud and clear as speakers made the business case for gender where multinationals should promote women run enterprises and jobs. Science and technology, particularly pharma and IT, were seen as on the forefront of development enterprise to test new drugs and to build new markets through mobile phones and computer links among young people. China was also on the cutting 
edge with discussions on how Chinese companies could invest in African land to solve fuel and food issues at home, and bring a potential new market for the Africans without attention required to dampening multilateral agreements. Greening the economy through more schemes like carbon trading was seen as a good way to share the burden of climate change across the rich and poor. Inclusive development meant more education, better health and social opportunities delivered through a mix of private and public enterprises according to market supply and demand. The crises of governance and the failure of overseas development aid required a shift from ODA to more efficient, green companies socially networked across the globe opening new markets and encouraging new consumer habits, particularly among the young, through tried and true western business models based on western scientific technology.

This is certainly one remarkably clear vision of development. Others, more on the margins of the development industry, are engaging in very different visions of what could be development. These visions steer away from the western ssumption of a linear line of progress, science and technology based on ever increasing wealth creation and market led growth, urban living and consumption. Rather, they take a more holistic view of development as a fluid process that requires living in harmony within and across communities and the Earth. The philosophical bases of such alternatives come from diverse contexts that respect the social and spiritual beliefs of non-western cultures and ways of seeing. Their standpoint acknowledges the violence of our global colonial history as well as questions contemporary market mechanisms consumerism.

In the hard-nosed world of economic development attention to such non-western views tends to be dismissed as romantic, unworkable, even backward. Who would not want the fruits of progress: a television set, a computer, a dishwasher, cheap flights? Look at all the rural migrants who (they would argue) chose to move to urban environments or even travel overseas away from their family, away from their land and culture in 430 order to work hard to purchase consumer goods and a better life? But is development simply about producing goods to satisfy people's desires for more and more consumer goods? Surely it is more complex. Why do people desire those goods? What system, what values, and what history has shaped the desires for those goods? And at what costs to the rural land, to society, to the culture, to the individual are those desired goods purchased?

There is a risk in taking up these issues as they go to the heart of what development is all about. There are a lot of people involved in the 'development industry' that do not want or see the need to challenge to scientific rationale of capitalist markets; they see their role as the delivery of modern western progress. However, even among those who work in the development field there are many who are increasingly deeply concerned about the 'violence of development' and the need for 'new institutions of development' (both titles of former Development journal issues). These critiques of mainstream economic development theory and practice emerge out of the experience, activism and alternative thinking that has been published in these pages on almost all areas of development.

Given the multiple crises we are now facing it seems increasingly important to count these view points as important voices of development. I would argue there is a sense of urgency that western-based development practitioners and thinkers learn from other cultures, rethink what is community, how to live with the Earth and embrace the spiritual with the material. Hence the decision to devote a journal issue to cosmovisions.

Cosmovisions means many things. ${ }^{1}$ In Development we have been exploring the term principally around the concept of conviviality and more recently the discussions on buen vivir (the good life, living well or collective well-being). Our approach is inspired largely by the Latin American experience in Bolivia and elsewhere, as well as the Ubuntu philosophy of sub-Saharan Africa.

There are many forms of cosmovisions. These worldviews are critical of western traditions of progress and modernity, which are expressed in western science, economics and military power. A central focus of this journal issue are the political and cultural struggles over land in 
Mexico. Several of the articles, put together by editorial board member Marisa Belausteguigoitia Rius from the Autonomous University of Mexico, record the voices of indigenous and rural peasant women (through two layers of translation). ${ }^{2}$ The articles mostly in the dialogue section are testimonies of their fight to keep their land, life and rights to water. The women's stories in different regions of Mexico tell of the shocking oppression and humiliation of their peoples. But also how, as they engaged in the struggles, women found their own voice and power, shedding the patriarchal oppression and invisibility of women in their own culture.

In another form of feminist engagement, Anita Gurumurthy looks at how to harness technology in a vision of alternatives led by transnational feminism seeking to change deep-seated patriarchal power in science, knowledge and practice. She advocates for savvy use of the master's tools. Isayvani Naicker, looks at the powerful African concept of Ubuntu engaging also with the insights of Franz Fanon on humanism and responsibility. She speaks of the need for a dialogue among western science and cultural traditions if we are to take up our global universal responsibility for peace and the protection of the Earth and its people, as envisioned by the Dalai Lama at Rio, 1992.

From another religious tradition, the Vatican aims to promote a different vision of development based on spirituality, human rights and charity. An interesting short article by Andrea De Angelis summarizes the official Vatican position. It is historically important to see how this strong hold of western religious power is echoing nondominant views of development. Most of the articles are based on less institutionally powerful social and spiritual beliefs in alternatives. They reject modernity because economic and military development processes directly violate their cultures and traditions.

The strong message of the journal's exploration of cosmovision continues to be inspired by buen vivir. Eduardo Gudynas and Bob Thomson give important summaries of the different forms of cosmovisions in Latin America and the interview with Gustavo Quilaqueo relates the history of the
Mapuches in upholding their cosmovision in the face of violent struggles in Chile.

The articles on buen vivir continue the conversation of an earlier contribution to Development by Catherine Walsh, ${ }^{3}$ who looked at how we can understand the emergence in the Andes Region and Ecuador of buen vivir as the guiding principle for a new regimen of development. She asks what the experiment in the Andes suggests for today's rethinking of development institutions.

She warns us that:

the new institutional arrangements of human centred development in South America, and particularly in Ecuador, are not without problems, inconsistencies, and contradictions. While the rest of the world may consider this case [with hope], as the dismantling of neo-liberal policies and the construction of endogenous development under a radically different life philosophy, the policies and practice emerging in the day-to-day indicate that the so-called 'citizen revolution' - if we can really call it that - has still some way to go. (Walsh, 2010: 21)

Interestingly, given the theme of the volume of 'sustainability', Walsh asks us to question how and if it is possible to disentangle the model of sustainable human development from the colonial past. She puts into question the whole possibility of sustainability if we fail to understand the geopolitics of development at this juncture. She reminds us of the importance to recognize, understand, unravel and change the unequal and violent power relations implicit in the dominant knowledge, vision and practice of development. There can no longer be development with a human face, it needs to include nature, and recognize the damage of the past if it is to move forward.

In choosing to open up the discussion around cosmovisions, this journal issue is an attempt to support the disentanglement of development from its colonial past. It asks the development community to take seriously the political, epistemic and creative power of the indigenous and rural communities in the Global South. Not all the voices of those who live by non-western cosmovisions are represented here by any means. But hopefully, this issue is a bridge to understanding what responsibility and justice could begin to 


\section{Development 54(4): Upfront}

look like, if the world views expressed in new republics, new constitutions and new movements and networks come into dialogue with the mainstream of the development industry.

\section{Notes}

1 A tiny sample of the scholarly debates in various fields of philosophy, agriculture, anthropology and geography can be viewed at: http://www.movingworldviews.net/Downloads/Papers/Escobar.pdf, http://www.compasnet.org/blog/ wp-content/uploads/2011/03/ARNS/arns.10.pdf, http://www.afes-press-books.de/pdf/Hexagon.3/OswaldIPRA.book,16 7.2008.pdf. See Window on the World this issue for another very small sample of civil society groups working with the concept in their advocacy and research.

2 Articles on the situation in Mexico were prepared and translated from papers given at two Symposia on 'Indigenous Women' leading War for Natural resources and Territorial Control coordinated and edited by María Isabel Belausteguigoitia Rius and edited by her together with Mariana Gómez and the editorial team Arehlí Galicia Santamaría, Claudia De Anda Angulo, Gerardo Mejía Núñez, Iraís Garcia Olvera, Iván González Márquez of the University Program of Gender Studies (PUEG) of the Autonomous University of Mexico.

3 See Walsh's article in Development, Volume 53 No. 1 'New Institutions for Development', downloadable for free on the Palgrave website (Walsh, 2010). Arturo Escobar has also led the discussions throughout his long and active association with the Development journal.

\section{Reference}

Walsh, Catherine (2010) 'Development as Buen Vivir: Institutional arrangements and (de)colonial entanglements', Development 53(1): 15-21. 